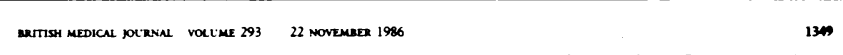
PRACTICE OBSERVED

\section{Research in Progress}

\section{Thirty one years of herpes zoster in a rural practice}

JOHN B WILSON

Abstreact

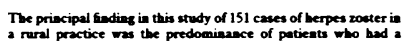

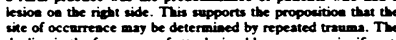

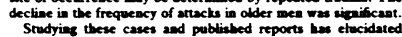

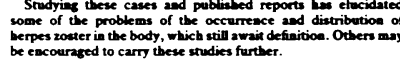

Introduction

Herpes zoster has held a great fascination for me during my 33 vears
in a rural pracuce in south west Scoothand. Over the years 1 have

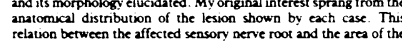

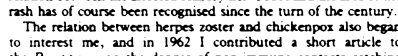

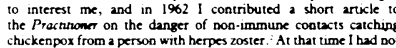

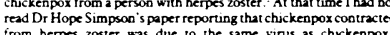
from herpes zoster was due to the same virus as chckenpox.
A feew years later Hope Simpson suggested that after an attack of
chickenpox the virus lies dormant in the sensory root, to be checkenpox the virus lies dormant in the sensory root, to be
reacurvated later erther by a reduction of the host's immunity or by

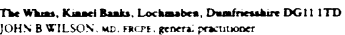

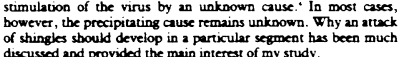 Findings

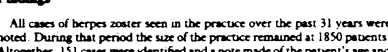

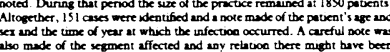

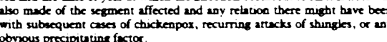

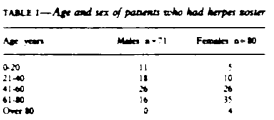

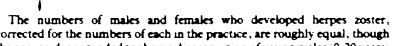

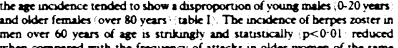

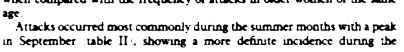

1350

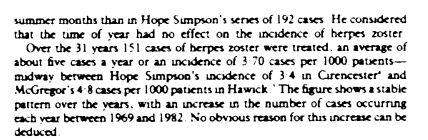

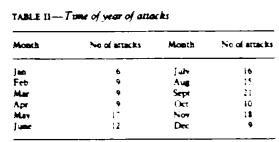

Hanchy

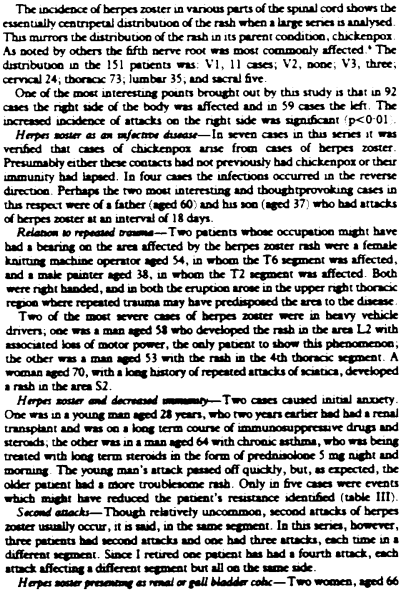

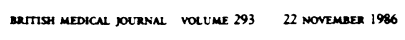

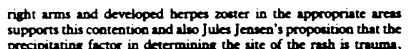
probably repeated rather then xurve.

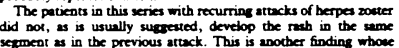

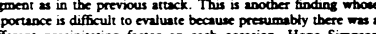

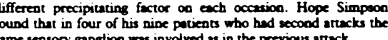

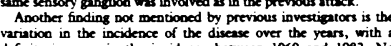

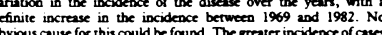

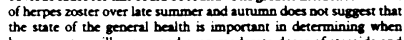

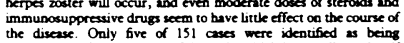

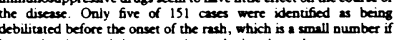
Leterd resistance is important in producing the rash.

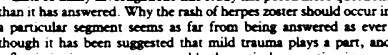

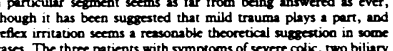
and one renal, seemed to promise more information and bopes that diseppointed. Apocher common source of refilex erritution would in

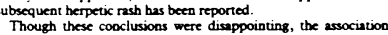

Good Practice

\title{
What is a good GP?
}

S G P WEBSTER

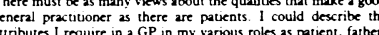

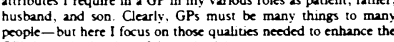

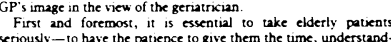

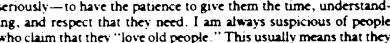

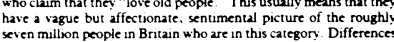

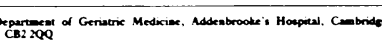

G GP XOQ

1352

logged consectuuve consultatons were concerned with pauents over
75 years of $28 \mathrm{tg}$. In addition. of 60 questions in the multuple choice question paper for the membership of the Royal College of General
Practitioners 1982-5, none could be classifed 25 "geratric medicine ". Less than $2 \%$ of general pracitioners are members
of the Briush Geriacrics Sociery. These may be unsatisfactory markers, but pacients commonily report that GPs dismiss the elderly
and their symproms. Reports from Age Concern paint a similarty bieak pheture.
Such a statc of affairs is bad for the current generation of elderly

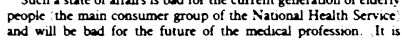
many stoics as a t present.) The introduction of good pracuce awards might be an opportuniry to correct this present sorry state of indifferencec Selecting farir and relevernt criteria, however, on which
to base such awards will be diffeult and contentious. Most

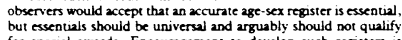

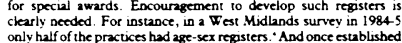

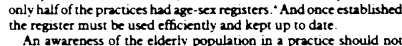

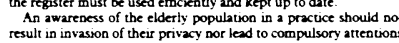

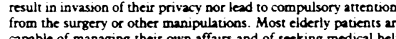
capable of managing their own affarss and of secking medical help
when necessary if they feel that the GP will be recepeive to their

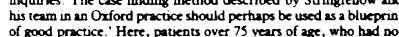

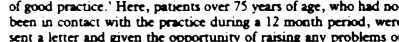

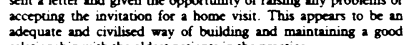

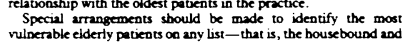

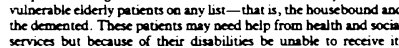

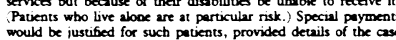

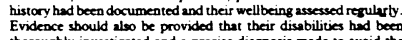

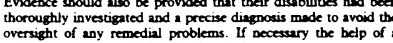

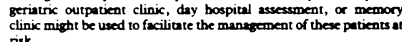

Hospital or hoses?

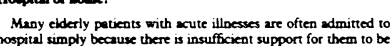

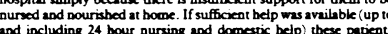

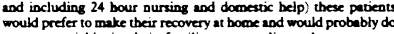

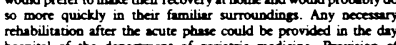
bospital of the depercment of exriertic medicine. Provision of

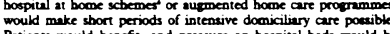

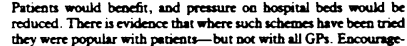
changes in their behaviour. The general prexuivoner and the

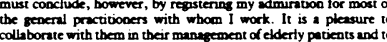

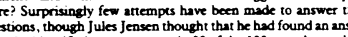

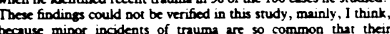

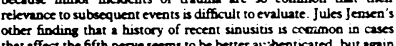
the tifch nerve seems to be bet Pertheps the mecthanism of this battei association lies in the referes

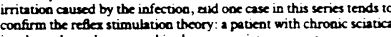
in whom the rash appeared in the appropriate segment.

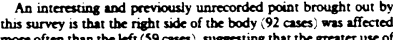

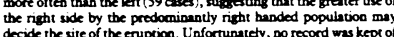

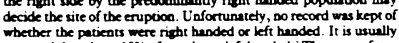

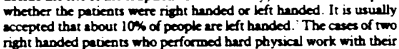
, = = = = =

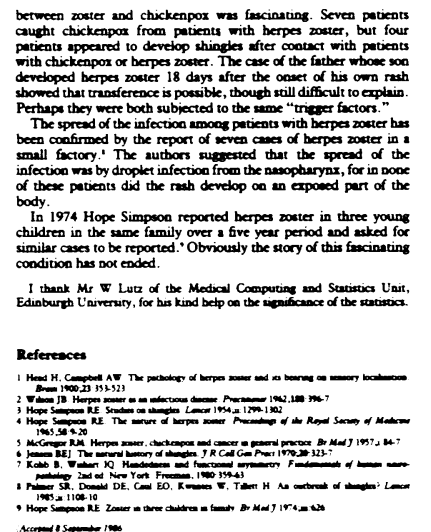

1351

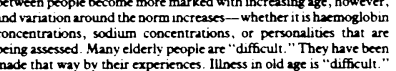
made that way by theire experienceses lilloess in old age is "difficult."
It presents in different forms and guises. The so called "silent

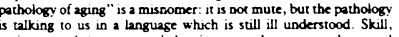
satien

Elderty are disergarded

Although there is good evidence of the need of elderly people for are reluctant to take these needs seriousty. Evidence from the examinations of the Rovel College of Generel Practitioners show

SRTIISH MEDICAL JOCRNAL VOLIME 29322 NOLEMBER 1986 ment will therefore be needed to entice the reluctant GP, and the
extra work required should be rewarded. The actuve suppor from GPs would make the growth of such schemes more likely, and good
practice awards for activites that are currently impossible to carry

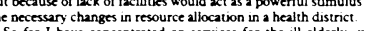
ckearly are a medical responsibibility. I would like, however, to see medical activity extending to the fit elderly, especially the young
old - those who have ust reached freurement age. Current retire

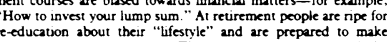
primes care tecam should capitalise one this and provide help in
retirement sessions at the health centre. The addition of "age well" and well to their programme of antenatal clesses, toddlet sessions laught to be more self relant and health conscious, and, in addition.

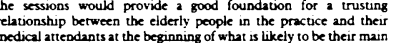
medical attendants a

\section{Sbow an interest}

The use of practice rewards should make it possible to encourage
improvemenos in medical care of the edderly - in most if not all aspects, but it is siso important to encourage continuing interest in

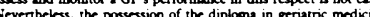
nay be a useful indicator. It is fashionable to deride exam but success in the diploma depends on the GP showing insight ins. toons. Proof that good prectices persist is even more difficult to

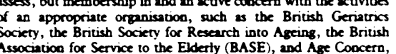
Association for service to the Ederty (BASE), and Ase Coocern,
might be useful markers.

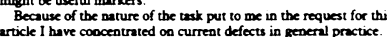

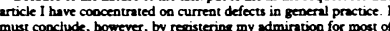

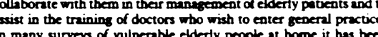

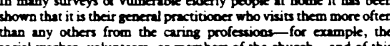

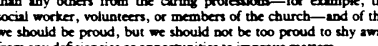

Retereser

Tism 